\title{
A HORA E VEZ DO HOMEM DO JUMENTO
}

\author{
Antônio Daniel FÉLIX \\ Sílvio Augusto de Oliveira HOLANDA
}

\section{RESUMO}

Este trabalho tem como objetivo fazer uma leitura de "A hora e vez de Augusto Matraga", uma novela de Sagarana (1983) de João Guimarães Rosa, analisando a recepção dessa novela a partir de três textos: Rolim (2005), Sousa (2014) e Oliveira (2015). Ao tomar como base a ideia de Ricoeur (2013), sobre O mundo do texto, seguido por seu conceito de que o texto literário seja de natureza discursiva, concretizando-se como um evento; a ideia de Jauss (1994a/1994b) de que o texto literário não surge num vácuo, pois não é de todo estranho ao seu público, bem como sua proposição de que a experiência estética se divide em dois momentos, um de identificação e outro de crítica (JAUSS, 1974); da mesma maneira como consideramos a ideia de Candido (2015) sobre a paradoxal existência do personagem; dentre outros pensamentos. Com base nessas premissas, visamos discutir a recepção da novela que apontamos como nossa base de análise e discussão.

PALAVRAS-CHAVE: Guimarães Rosa; Sagarana; Recepção.

\section{LA HORA Y TURNO DEL HOMBRE DEL BURRO}

\section{RESUMEN}

Este artículo tiene como objetivo hacer una lectura de "La hora y turno de Augusto Matraga”, una novela de Sagarana (1983) de João Guimarães Rosa, así como analizar la recepción de esta novela basada en tres textos: Rolim (2005), Sousa (2014) y Oliveira (2015). Basado en la idea de Ricoeur (2013) sobre El mundo del texto, seguido de su concepto de que el texto literario es de naturaleza discursiva, materializándose como un evento. La idea de Jauss (1994a / 1994b) de que el texto literario no emerge en el vacío, ya que no es ajeno a su audiencia, así como su proposición de que la experiencia estética se divide en dos momentos, uno de identificación y otro de crítica (JAUSS, 1974); tal como consideramos la idea de Candido (2015) de la existencia paradójica del personaje; entre otros ideas. Con base en estas premisas, nuestro objetivo es discutir la recepción de la novela que señalamos como nuestra base para el análisis y la discusión.

PALAVRAS-CLAVE: Guimarães Rosa; Sagarana; Recepción.

\section{THE HOUR AND TURN OF THE DONKEY'S MAN}

\section{ABSTRACT:}

This paper aims to make a reading of "The hour and turn of Augusto Matraga", a short story of Sagarana (1983) by João Guimarães Rosa, as well as to analyze the reception of this short story based on three texts: Rolim (2005), Sousa (2014) and Oliveira (2015). It is taken as basis the idea of Ricoeur (2013) about The world of the text, followed by his concept that the literary text is a discursive one, materializing itself as an event; Jauss's (1994a / 1994b) idea that the literary text does not emerge in a vacuum, as it is not at all foreign to its audience, as well as his proposition that the aesthetic experience is divided into two moments, one of identification and the other of criticism (JAUSS, 1974); the same way, we consider Candido's (2015) idea of the paradoxical existence of the character; among other ideas. Based on these premises, we aim to discuss the reception of the short story that we pointed out as our basis for analysis and discussion.

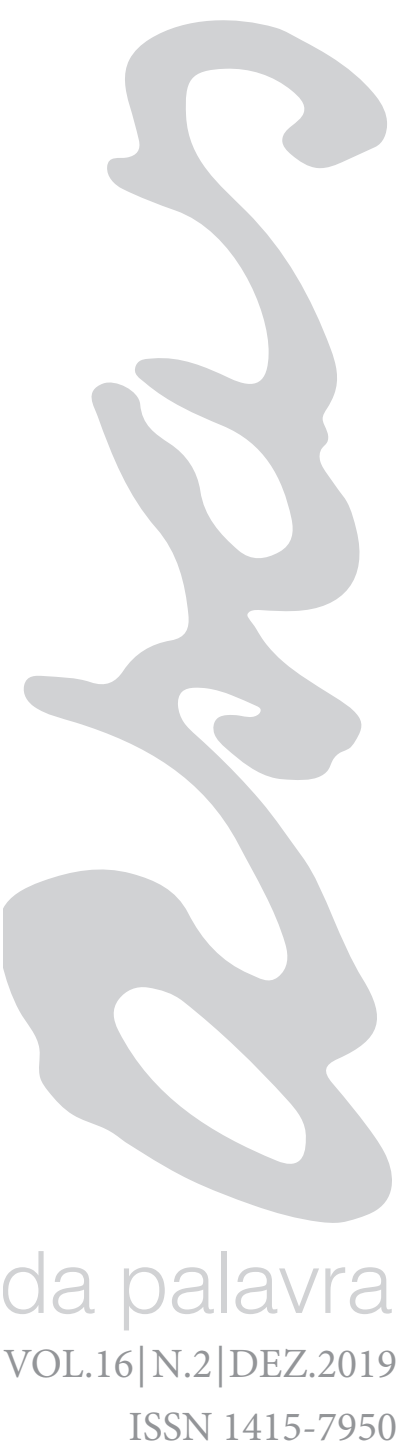

KEYWORDS: Guimarães Rosa; Sagarana; Reception. 


\section{“A HORA E VEZ DE AUGUSTO MATRAGA": UMA SÍNTESE}

A novela de Guimarães Rosa, basicamente, divide-se em três partes (FREIXEIRO, 1971). Podemos dizer que, embora a avó de Nhô Augusto tenha tentado conduzi-lo à vida religiosa, provavelmente, tal qual tentara com seus filhos, suas tentativas falharam. No entanto, diferentemente de seu pai que possuía riquezas, Nhô Augusto cai em infortúnio após a morte do progenitor. Ao ser abandonado por sua esposa e por sua filha, bem como por seus capangas, num ato de desespero por uma retomada de controle social, com o qual estava acostumado desde sua infância, Nhô Augusto tenta resgatar seu poder social ao enfrentar seu Major Consilva sozinho. Este é inimigo de sua família, herdado como herança de seu pai. "- Cachorrada!... Só de pique... Onde é que eles estão? / — Indo de mudados, p'ra a chácara do Major... / — Major de borra! Só de pique, porque era inimigo do meu pai!...” Vou lá! (ROSA, 1983, p. 330).

Dessa forma, a novela de Guimarães Rosa, mostra-nos um filho fiel ao poderio da comunidade em que crescera. Nhô Augusto, desde cedo, provavelmente, sob a tutela de seu pai, usufruiu do poder sobre os demais capiaus que o circunscrevia. Assim, o protagonista tinha a provável sensação de ser dono da vida dos outros. Ele é, portanto, um agente ativo, que manda e desmanda no arraial, sendo, no entanto, fruto da comunidade em que crescera. Alucinado por seu suposto poderio, sentindo-se o todo poderoso, Nhô Augusto sai ao confronto de seu maior inimigo, mas é abatido por seus ex-capangas. Sua queda encerra-se com um ato de humilhação maior, quando o grande senhor Augusto Esteves é marcado a ferro, como se fosse propriedade de seu Major Consilva, o que, além de humilhante, configura-se como um suposto castigo por suas atitudes transgressoras.

Num ato desesperador, Nhô Augusto salta de um barranco e é considerado como morte. Sem qualquer esperança de vingar sua desgraça, tendo em vista a incapacidade de seu corpo, ele reflete sobre sua vida e decide que é melhor viver. Considerando que o homem não poderia viver sem motivo, Nhô Augusto toma por objetivo de vida a absolvição de seus supostos pecados; de modo a recuperar-se com segurança, o protagonista foge para o Povoado do Tombador, levando consigo o casal de "pretos" que o resgatou e resguardou.

A partir do momento em que Nhô Augusto reflete sobre suas atitudes passadas, ele sente-se horrorizado e, em virtude disso, a fim 
de compensar sua vida passada, bem como, supostamente salvar, sua alma, este ajuda aos outros gratuitamente. Sabendo que seu corpo está impossibilitado de brigar, de beber cachaça, assim como de usufruir do prazer sexual, ele tenta evitá-los, dando a si trabalho e reza. Não obstante, o suposto penitente não consegue esquecer de seu passado.

Um eventual reencontro com Tião da Thereza inflama a agonia de Nhô Augusto em relação a seu passado e sua perturbação chega ao nível mais elevado, quando este sabe que seu mais fiel capanga tinha morrido tentando desforra em seu nome. Tal informação, trazida por seu velho conhecido, o faz sentir-se diminuído em sua homência: “[...] o Quim Recadeiro - um rapazinho miúdo, tão no desamparo - e morrendo como homem, por causa do patrão... Um patrão de borra, que estava p'r'ali no escondido, encostado, que nem como se tivesse virado mulher!..." (ROSA, 1983, p. 343).

O discurso do protagonista mostra que ele se sente enfraquecido pelos atos religiosos que tem praticado, sentindo-se como se tivesse virado mulher e fosse menos que Quim, que teria morrido como homem. Além disso, o olhar de desprezo de Tião da Thereza, reforça tal ideia, a de que Nhô Augusto, como homem, deveria vingar sua desonra. Em virtude disso, o protagonista reclama-se à mãe Quitéria, afirmando que:

Essa reclamação demonstra a superação do protagonista em relação ao seu tormento do passado. Após a passagem de Joãozinho Bem-Bem e parte de seu bando por sua casa, numa dada manhã, Nhô Augusto decide que é hora de ir embora. E vai.

Em meio a viagem, o protagonista diz ao cego que encontra e "ao cerrado", metaforicamente, que: "Oh coisa boa a gente andar solto, sem obrigação nenhuma e de bem com Deus!..." (ROSA, 1983, p. 359). Nhô Augusto sente-se sem qualquer obrigação de vingar qualquer coisa, uma vez que, com seu período de reflexão, este chegou à provável conclusão de que não há do que se vinga, considerando que tudo o que lhe aconteceu, adveio de seus próprios atos. Assim, ele aceita seu passado e anda de bem com Deus. Este andar de bem com Deus seria uma metáfora para de bem com minha própria consciência, isto 
é, nada mais o tormenta, embora, claro, ele carregue em sua memória todo seu passado.

Ao chegar ao arraial do Rala-Coco, Nhô Augusto encontra seu amigo Joãozinho Bem-Bem e é noticiado sobre a morte à traição de seu colega Juruminho, um dos melhores jagunços de seu Joãozinho Bem-Bem. Abruptamente, a conversa entre o protagonista e o chefe jagunço é interrompida pelo pai do assassino que teria fugido. Em virtude da fuga do assassino e em obediência aos costumes jagunços, Joãozinho Bem-Bem quer matar um dos irmãos do assassino; de qualquer forma, este, em sua bondade, considera justo que o pai escolha qual filho terá que morrer.

O pai implora ao chefe jagunço que ordene somente a morte dele, dispensando suas filhas e filhos. Por causa da recusa de seu Joãozinho Bem-Bem, o velho pai exclama: “- Pois então, satanás, eu chamo a força de Deus p'ra ajudar a minha fraqueza no ferro da tua força maldita!...” (ROSA, 1983, p. 363).

Esse final, às vezes, é interpretado com um fundo religioso. No entanto acreditamos ser interessante considerar que: a) se Deus é amor e perdão, então, numa suposta Imitatio Christi, o velho pai deveria perdoar o assassino de seu filho, da mesma forma em que, ao presenciar tal assassinato - que não seria de todo injusto, segundo a lógica implícita da novela, expressa por Tião da Thereza, Nhô Augusto, logo após sua queda, e Joãozinho Bem-Bem — Nhô Augusto deveria orar pelas almas dos mortos e consolar o velho pai e seu Joãozinho Bem-Bem pela perda das pessoas queridas; b) o clamor do velho pai a Deus, em sua proteção, nada mais é do que uma metáfora que visa a comoção de alguém presente nas proximidades e que, porventura, possa socorrê-lo; c) Nhô Augusto não intervém, provavelmente, por que acredita ser um chamado divino, mas sim, porque considera a humilhação e maltrato a capiaus indefesos um ato horroroso - uma vez que ele se sentiu horrorizado após refletir sobre suas ações passadas - e que lhe seria muito desonroso - tendo em vista seu desejo de fazer algo de vantagem, isto é, algo, para ele, bom, em honra ao Quim que morreu por ele - assistir aquela cena de humilhação e destruição de uma família sem fazer nada.

$\mathrm{O}$ ato final de Nhô Augusto coincide com sua morte, assim como com a morte de seu Joãozinho Bem-Bem e parte de seu bando. 
massa. Dizer matar em prol da vida não se sustenta, como obra divina ou qualquer outra coisa que, possivelmente, possa levar à salvação. Neste caso, Nhô Augusto simplesmente faz o que acredita ser o correto, tomado pelo momento, muito embora, ele ainda acredite numa possível salvação, sua salvação.

Com base nos pontos destacados da novela, temos, então, três momentos: o da valentia e inimizade herdada de seu pai, o de seu sofrimento e recuperação, e, por último, o de sua morte.

Para além da novela, mas ainda sobre ela, o momento em que Nhô Augusto se encontra na beira da morte, ele pula o barranco. Seu pulo é movido por uma necessidade, coincidindo com a segunda epígrafe da novela "Sapo não pula por boniteza, mas porém por percisão.” (ROSA, 1983, p. 321). Já no início do segundo momento, Nhô Augusto é pobre de espírito e precisa ir embora, de modo mudar de vida. Após sua recuperação corporal e sua elevação de espírito, ele vai embora novamente, o que coincide com a primeira epígrafe da novela "Eu sou pobre, pobre, pobre, vou-me embora, vou-me embora / Eu sou rica, rica, rica, vou-me embora, daqui!..." (ROSA, 1983, p. 321). Vistas nessa ótica, as epígrafes seriam como uma síntese dos acontecimentos desde os quais a novela se desenvolveria.

Diante desta síntese da obra, pretendemos apresentar a recepção da mesma a partir do ponto de vista dos pesquisadores: Oliveira (2015), Rolim (2005) e Sousa (2014), seguida das reflexões sobre qual o papel do leitor na obra em análise e as considerações finais.

\section{OLIVEIRA (2015)}

Oliveira, em sua dissertação, centraliza-se no personagem principal, em seu desenvolvimento ao longo da narrativa, que é a comparada, inúmeras vezes, com a vida percorrida por Francisco de Assis, chegando, em determinados momentos, a ser comparada com a de Jesus Cristo. Seu intuito é analisar a "influência do sagrado, da religião e da religiosidade na construção de um santo popular, considerando, como ocorre essa construção e o caminho seguido pela personagem no processo de santificação.” (OLIVEIRA, 2015, p. 08)

Podemos, pois, corroborar, de início, que sua argumentação se baseia numa fundamentação religiosa, uma vezque — desde o princípio, ao discutir sobre as leituras de Guimarães Rosa - o pesquisador 
assegura que "Os livros espirituais que compõem sua biblioteca, seguramente, influenciaram na sua escrita e, consequentemente, na construção da personagem Matraga.” (OLIVEIRA, 2015, p. 13). Dessa forma, fica claro que dentre as inúmeras possibilidades de leitura cabíveis à novela, Oliveira busca a de natureza religiosa, considera-a tão predominante que afirma o seguinte: “Ao se ler o conto, vê-se claramente que Rosa constrói uma personagem que atinge a santidade ao final da vida através do martírio." (OLIVEIRA, 2015, p. 13).

No que diz respeito ao nome do personagem principal, Oliveira argumenta que "Nas ordens religiosas era comum a troca de nome ao se fazer a profissão religiosa. A troca simbolizava o nascimento de um novo homem para Deus, e geralmente se escolhia um nome de santo como nova identidade." (OLIVEIRA, 2015, p. 35). Guiado por sua vontade de mostrar que um personagem fictício pode ser considerado santo, Oliveira prepara sua argumentação chave, afirmando que "A jornada feita por Matraga insere seu nome no rol dos santos populares, ou seja, pessoas que são veneradas como santas pelo povo, ainda que não figurem no cânone católico." (OLIVEIRA, 2015, p. 86). Asseverando, por fim, que, com base em sua argumentação, "Morre a personagem de Rosa e surge o santo Matraga, o santo da literatura de Rosa." (OLIVEIRA, 2015, p. 91). Sua argumentação fecha com a apologia de uma possível existência de um santo popular advindo da literatura. Mas como poderia um ser fictício ser considerado santo? E se pudesse, poderia Augusto Matraga ser considerado santo?

Se levarmos em conta a novela em questão em sua integridade, não podemos considerar Augusto Matraga como santo, visto que, para supostamente se tornar santo, ele comete um pecado, que seria o homicídio de seu Joãozinho Bem-Bem e parte de seu bando que o acompanhava. De fato, Augusto Matraga encerra sua história cometendo um homicídio em massa.

Por outro lado, podemos, sim, levar em consideração o fato de que o personagem, em seus últimos atos, pede a seu primo - João Lomba - que diga a sua ex-mulher que o abandonou que está tudo bem, isto é, que sua traição foi perdoada por ele, bem como pede que este ponha a benção sobre sua filha. Não obstante, tais atitudes não apagam de sua história de vida todos seus atos de perversão e maldade, mas, por outro lado, opõem-se a eles, de modo a "anulá-los", de tal forma que haja a possibilidade do personagem ter absolvição de seus 
REVISTA DO PROGRAMA DE PÓS-GRADUAÇÃO EM COMUNICAÇÃO, LINGUAGENS E CULTURA DA UNIVERSIDADE DA AMAZÔNIA

pecados, em virtude de seus bons atos praticados na última metade de sua travessia.

Mesmo que Oliveira queira mostrar o personagem principal como um santo, ele é textualmente obrigado - considerando o que o texto permite ou não que seja dito sobre ele - a reconhecer que "Inicialmente, a personagem se revela e se iguala a um pecador" (OLIVEIRA, 2015, p. 16), além de "fazer alusão ao uso da violência para adentrar ao céu. O que, em tese, é totalmente contrário aos valores divinos e à moral religiosa." (OLIVEIRA, 2015, p. 25).

Augusto Matraga não só faz alusão à violência para adentrar ao céu, ter seus pecados absolvidos, como finaliza sua história com porrete, melhor dizendo, porrada. Dessa maneira, consideramos que seja mais adequado considerar que o personagem se aproxime do humano, do desenvolvimento humano, visto que o protagonista, em sua ignorância e cego pelo suposto poder que tem, maltrata tanto seus familiares quanto toda a comunidade em que vive; tendo como resultado desses atos da juventude um castigo, que o leva ao amadurecimento quanto pessoa. Com base em seus atos passados, o personagem busca atitudes compensadoras, de modo a ter uma nova vida, acompanhada de uma nova avaliação social.

Quando o personagem vê-se num contexto de maldade e humilhação em relação a um velho que não tem homênica suficiente para resguardar a própria familiar, ele sente-se na obrigação de — de modo a recompensar seus atos passados e fazer jus a sua homência, bem como experimentar sua força, divertir-se numa luta com um oponente tal qual seu Joãozinho Bem-Bem, além de sentir-se honrado ao salvar vidas; ele que foi motivo da morte de Quim e do sofrimento de Dionóra, como a esposa em desleixo, bem como do sofrimento do pobre capiau apaixonado e da dor de rejeição sofrida por Sariema, a humilhação de seus capangas e outras pessoas da comunidade tentar salvar o velho e sua família.

\section{ROLIM (2005)}

Rolim, em sua dissertação de mestrado, objetiva analisar as obras "História de Roberto do Diabo, de Leandro Gomes de Barros, O Ermitão de Muquém, de Bernardo Guimarães, e 'A hora e vez de Augusto Matraga', de João Guimarães Rosa.” (ROLIM, 2005, p. 06) com o intuito de evidenciar "uma estreita ligação entre elas, através 
dos elementos temáticos e formais que as compõem.” (ROLIM, 2005, p. 06). Não obstante, ao analisar a novela em questão aqui, assim como Oliveira (2015), faz uma leitura de natureza religiosa. Por outro lado, diferente de Oliveira (2015), ele não propõe nenhuma consideração do personagem tal como um santo real, embora Rolim (2005) considere que o protagonista se torne santo ao final de sua travessia. Em síntese, Rolim assegura que

[...] podemos dizer que o conto de Guimarães Rosa evidencia um processo de santificação no qual o protagonista, primeiramente visto como um bandido, transforma-se num homem bondoso, que busca na penitência a salvação de sua alma, mas que somente a encontrará nas mesmas armas que possivelmente o condenariam ao inferno. Todavia, usando-as em favor daqueles que em Deus buscam seu auxílio. (ROLIM, 2005, p. 74-75)

Em sua síntese, Rolim coloca o protagonista como um bandido, no entanto, não consideramos que seja possível tal colocação, uma vez que o texto, em si, não permite. A novela mostra um personagem autoritário, em seu início, não um bandido. Além disso, reiteramos que não consideramos que o protagonista alcance a salvação. Sobre isso, Rolim cogita tal possibilidade, afirmando que "[...] é notória a transformação na conduta de Nhô Augusto, mas ainda assim pouco provável a sua salvação.” (ROLIM, 2005, p. 75), embora o pesquisador conclua que o personagem se torne santo.

Ao considerar que o herói se metamorfoseia, de bandido a santo, Rolim afirma que tal mudança se inicia, de fato, quando Nhô Augusto se muda para o Tombador: "Sua vida é muito estranha àqueles que a observam, quase escravo, devoto, sem passado e sem anseios mundanos, por conseguinte, esta é claramente a etapa na qual se inicia a remissão dos atos desumanos realizados numa vida anterior, a de Augusto Esteves." (ROLIM, 2005, p. 79).

É interessante observar que, embora Rolim já tenha considerado que "[...] vale lembrar o uso constante da alcunha Nhô Augusto, que atravessa todos os três momentos" (ROLIM, 2005, p. 73) nos quais é, usualmente, dividida a travessia do protagonista. Rolim, ao observar a mudança de comportamento de Nhô Augusto, o colocou como se este não se fizesse presente em todos os momentos da história, ao situar Augusto Esteves como o protagonista do período anterior a sua queda e Nhô Augusto como o do período pós-queda. 
Ao escrever sobre o pronome de tratamento atribuído a Nhô Augusto, Rolim bem observa que “[...] a alcunha Nhô Augusto associa a derivação popular de um pronome de tratamento: senhor — sinhô — nhô" (ROLIM, 2005, p. 73). Para além disso, antes de iniciar sua discussão final, sobre o último período que compõe a travessia do protagonista, Rolim considera "importante observar como as duas primeiras partes estão divididas por um maniqueísmo manifesto segundo as ações do protagonista." (ROLIM, 2005, p. 80). Ao fazer essa colocação, Rolim deveria, antes de qualquer coisa, dizer o que seria maniqueísmo.

Se tomarmos como fundamento para tal colocação que maniqueísmo é um pensamento de natureza religiosa e absolutista que considera a vida dividida entre $\mathrm{Bem}$ e $\mathrm{Mal}$, sem que estes dois se misturem. Então, somos instigados a considerar que Rolim cometeu um equívoco em sua colocação, pois, como afirma Sousa (2014) “Augusto Matraga é, ele próprio, uma encruzilhada, na qual se debatem ou se cruzam o bem e o mal" (SOUSA, 2014, p. 26). Dessa forma, torna-se visível que o texto não permite tal colocação maniqueísta.

Quando Rolim discute o terceiro período da travessia de Nhô Augusto, ele observa que "[...] se nota a união de Matraga com a obra divina, a sua relação com a natureza se torna mais e mais evidente." (ROLIM, 2005, p. 79). Sua colocação abre alas a um questionamento pertinente. Se Nhô Augusto aproxima-se mais e mais da obra divina à medida em que se aproxima da natureza, seria, então, supostamente, só a natureza que comporia a obra divina? No momento em que Nhô Augusto se desprende de suas correntes religiosas às quais foi preso pelo discurso de cunho religioso - proferido, inicialmente, por sua avó e, depois, mais provável, por pai Serapião e mãe Quitéria, seguidos pelo padre - e entra em um combate fatal com seu Joãozinho BemBem e parte de seu bando, morrendo, ao mesmo tempo em que mata o chefe jagunço e, provavelmente, parte de seus companheiros, ele não estaria se distanciando, novamente, da obra de Deus? Se considerarmos que Nhô Augusto estaria indo contra a vontade divina, que seria a de não matar.

De uma forma ou de outra, Rolim finaliza sua argumentação considerando que "de um pólo a outro, a ligação entre as trajetórias de Matraga e São Paulo ${ }^{1}$ é evidente, da barbárie à santidade, cada qual
$1 \mathrm{Na}$ dissertação de Rolim, Matraga é comparado a São Paulo duas vezes. (ROLIM, 2005, p. $83 ; 84)$ 
em seu tempo, e ao seu modo, santos." (ROLIM, 2005, p. 84). Enfim, tanto Oliveira (2015) quanto Rolim (2005), desconsideram o massacre feito por Nhô Augusto em seus últimos atos, de modo a declararem-no santo.

\section{SOUSA (2014)}

Sousa, em sua tese, objetiva fazer uma leitura de cinco contos — dentre eles a novela que aqui discutimos — com a intenção de “observar na gênese criativa do autor uma temática maniqueísta, em cuja concepção do mundo, com intensidade poético, opõe-se o bem e o mal." (SOUSA, 2014, p. 07). Não obstante, assim como Rolim (2005), Sousa (2014) não faz qualquer definição sobre o maniqueísmo. Por outro lado, diferente de Rolim (2005), Sousa (2014), considerando a complexidade do protagonista, refuta a possibilidade de leitura de "A hora e vez de Augusto Matraga" com uma temática maniqueísta.

Como não intencionamos observar necessariamente as mesmas coisas consideradas pela maioria dos leitores da novela, mas sim, o que há de mais peculiar em cada leitura, não exploraremos as considerações de Sousa em relação aos dois primeiros momentos da novela, tendo em vista que em nada acrescentaria à nossa discussão, pois tão somente repetiríamos pontos comuns a maioria das interpretações.

Antes de adentrarmos a discussão de Sousa (2014), é interessante revermos alguns pontos. Sousa (2014) afirma que Nhô Augusto, após arrematar Sariema, "manda estapear o capiauzinho amoroso." (SOUSA, 2014, p. 18), no entanto, o texto de Rosa não permite que tal atribuição seja feita a ele, uma vez que, ao ver, em meio a confusão que se instaura, o capiau amoroso tentando sair da multidão levando Sariema consigo, o próprio Nhô Augusto o agride, em função de tomar Sariema de volta. Em nenhum momento, o texto nos afirma ou deixa implícito que haja ordem de Nhô Augusto para que alguém agrida o capiau.

Sousa (2014) assevera que "Nhô Augusto é encontrado por um casal de pretos" (SOUSA, 2014, p. 19). Tal afirmação não é admitida pelo texto, pois este diz que o protagonista foi encontrado pelo "preto" que, ao encontrar vida no corpo de Nhô Augusto, volta e pede ajuda à "preta" para carregá-los até onde moravam.

Sousa (2014) assegura que "surge Joãozinho Bem-Bem, famoso líder de jagunços, que em agradecimento a estadia oferecida por Nhô Augusto o convida para acompanhar seu bando." (SOUSA, 2014, p. 20). 
Essa colocação não é aceita pelo texto, visto que, em agradecimento à estadia de Nhô Augusto e seus "pais adotivos", seu Joãozinho BemBem oferta seus serviços de jagunço. O oferecimento de uma vaga em seu bando a Nhô Augusto surge de um interesse do chefe jagunço pelas prováveis habilidades de combate deste observadas por aquele.

Sousa (2014), observa que, Tião da Thereza, noticia Nhô Augusto de que "Dionóra vivendo de bem com o amante, Mimita prostituída e Quim Recadeiro, seu fiel comparsa, morto por causa dele" (SOUSA, 2014, p. 22). O caso de Mimita é delicado. O narrador, descrevendo o dito por Tião a Nhô Augusto, informa que a Mimita “crescera sã e se encorpara uma mocinha muito linda, mas tinha caído na vida, seduzida por um cometa, que a levara do arraial, para onde não se sabia..." (ROSA, 1983, p. 341). No popular, cair na vida pode significar duas coisas: ir embora ou prostituir-se. Se fosse o segundo caso, o da prostituição, seria muito provável que o texto informasse tão somente que Mimita caiu na vida, o que, ainda assim, seria ambíguo. Por outro lado, e, nesse caso, mais provável, pode significar ir embora, pois quando o narrador informa que ela caiu na vida com alguém, ele restringe o sentido ao ir embora.

Adentrando a discussão abordada por Sousa (2014), ela começa sua análise afirmando que "[...] se todo valor é relativo, o bem não é mais que uma ilusão" (SOUSA, 2014, p. 18), considerando, portanto, que tanto o bem quanto o mal depende de um crente e que, para além disso, uma coisa ou ação pode ser tanto boa quanto má, dependendo do ponto de vista, se se considerar que todo valor é relativo.

Sousa (2014) observa que "Após a partida de Joãozinho Bem-Bem e do estímulo da tentação, Matraga parece apaziguado, se concedendo pequenos prazeres sem o temor do pecado e não pensando mais em morrer e nem em ir para o céu." (SOUSA, 2014, p. 24). A pesquisadora considera, a partir desse momento, que o protagonista se desprende de suas crenças e torna-se um ser mais consciente e independente. uma visão valorizada do mundo, parece já contraporse, paradoxalmente, ao ideal suprassensível do céu, como se o personagem, tocado pelo trágico pensamento nietzscheano, defendesse a alegria de viver, como os helênicos da Grécia arcaica, os quais, segundo o filósofo, esboçavam um perfeito equilíbrio entre o dionisíaco e o apolíneo, ou seja, entre o sonho 
e a embriaguez. Ultrapassando, portanto, o desmando de sua primeira fase no conto, em que, violento e autoritário, representa o poder no povoado do Murici, no qual arremata a Sariema e mostra-se voltado para a vingança, e sobrepondo-se também ao momento posterior à queda do barranco, quando se volta para a retidão do espírito, seguindo os conselhos do padre, a esperar pelo céu, a terceira fase de Matraga parece harmonizar os caracteres de Dioniso e Apolo, que se estabelecem no personagem após o conhecimento das notícias levadas pelo Tião da Theresa. (SOUSA, 2014, p. 30)

Essa arguição de Sousa (2014) é fundamentada pelo pensamento de Nietzsche que, por sua vez, "analisa a condição humana, sobretudo as constantes transformações sofridas pelos seres humanos, advindas de suas atitudes, certas e erradas." (SOUSA, 2014, p. 37). Pensando a complexidade do protagonista, que se mostra ora bondoso, ora maléfico, Sousa (2014) considera que o pensamento do filósofo alemão, sobre as transformações humanas, aplica-se é aplicavel à novela de Guimarães Rosa, considerando que "Essas mudanças podem ser observadas no interregno que estende-se do Nhô Augusto inicial da novela ao Augusto Matraga do término da estória, quando então o personagem encontra sua hora e vez." (SOUSA, 2014, p. 37). Para além disso, a pesquisadora observa que essa complexidade de transformações humanas presente no personagem de fiç̧ão é explorador mais largamente pelo autor mineiro, afirmando que "os seres humanos seriam criadores dos seus próprios projetos de vida, ou dos seus motivos para viver, como fizeram ficticiamente Riobaldo e Matraga." (SOUSA, 2014, p. 36)

Se no primeiro momento o protagonista tinha seu comportamento baseado nas normais sociais vigentes; se no segundo momento, ao se ver enfraquecido, o protagonista se deixa levar por um discurso religioso proveniente de um dado grupo social; se suas decisões até então foram tomadas com base em discursos alheios, neste terceiro momento, poderíamos dizer que Nhô Augusto formula sua própria ideia, seu próprio jeito de ser. Diferente do primeiro e do segundo Nhô Augusto. Um terceiro. Melhor que os anteriores. Com base nisso, Sousa (2014) conclui que 
libertar-se de grilhões metafísicos, ou seja, da moral cristã em que se apoia na intenção de transformar-se em um homem melhor. Parece mesmo não esperar mais pela recompensa celestial, contentando-se então com a felicidade do velho que implora pela vida do filho. Sem medo da punição divina, pretendendo apenas estar bem com sua consciência, Nhô Augusto descarta a ascese e coloca-se além do bem e do mal, sob uma interpretação moral própria, ou melhor, numa transvaloração de valores, em cuja peculiar justiça visa o porvir, o buscado céu matraguiano, por ele assim, talvez, compreendido. (SOUSA, 2014, p. 34)

Pondo-se além dos preceitos sociais, Nhô Augusto ou o Homem do Jumento, como este fica socialmente conhecido no final, encerra sua travessia com sua consciência em paz. Se seus atos finais foram bons ou males, pouco importa, ele fez o que julgou que deveria fazer e se foi contente disso.

\section{(IN)COINCIDÊNCIAS INTERPRETATIVAS}

Ao tomarmos ciência de que o texto literário não muda, em seu interior, apresentando-se materialmente da mesma forma, abrindo-se a interpretação no ato da leitura à medida em que, de certa forma, guia a multiplicidade de interpretações possíveis, não é de estranhar que, num momento ou noutro, haja interpretações sobre uma mesma passagem estranhas entre si, mas válidas, textualmente aceitáveis. Por outro lado, há a possibilidade de interpretações semelhantes, mas textualmente inviáveis. Aqui, podemos apreciar interpretações como tais.

Tanto Oliveira (2015), quanto Rolim (2005) veem uma proximidade entre a chegada de Jesus Cristo à cidade de Jerusalém e a chegada de Nhô Augusto ao arraial do Rala-Coco. Aquele observa que a "entrada de Matraga na cidade que é o oposto da entrada de Jesus. A agitação que Matraga encontra não é causada por sua chegada, mas, sim, pela chegada do bando de Joãozinho Bem-Bem." (OLIVEIRA, 2015, p. 32). Daí, Oliveira considera que chegará a hora e vez de Augusto Matraga. Rolim (2005), por sua vez, não parte da comparação entre as chegadas de Jesus e Matraga, mas da observação de que tanto um quanto o outro chega montado em um jumento; daí Rolim observa que: "a ligação mais notória entre a figura do jumento e a santidade está na chegada de Jesus em Jerusalém, montado num burrinho e que, além disso, Ele também encontraria sua hora dias depois." (ROLIM, 
2005, p. 80). De fato, um e outro observam o mesmo fato textual cada qual baseado em sua perspectiva.

\section{LEITOR E OBRA}

Nem toda interpretação cabe à obra literária em sua integridade, nem toda interpretação conclui um personagem, principalmente quando este é de complexidade tal qual a de Nhô Augusto. Se considerarmos como princípio que o texto literário é uma "forma acabada e fechada em sua perfeição de organismo perfeitamente calibrado, é também aberta, isto é, passível de mil interpretações diferentes, sem que isso redunde em alteração de sua irreproduzível singularidade.” (ECO, 2015, p. 68). O texto literário, em seu fundamento, direciona a interpretação à medida em que a deixa em aberto, isto é, dependente do conhecimento prévio e do ponto de vista escolhido pelo leitor. A exemplo disso, vemos a interpretação de Oliveira (2015) e Rolim (2005) sobre a chegada de Jesus Cristo e Nhô Augusto, ambas válidas, embora sejam relativamente diferentes.

A coincidência ou proximidade interpretativa dá-se com base numa sugestão textual alicerçada por um conhecimento prévio existente no interior da obra e de posse do leitor (JAUSS, 1994a), considerando que a obra não surge num vácuo, mas sim, numa tradição literária, além de tomar a realidade como base de sua criação; isso permite a Hans Robert Jauss observar que é esse conhecimento prévio que possibilita a relação entre o leitor e a obra. Mais adiante, o crítico alemão reitera isso afirmando que "Se o estranho de um texto ou pessoa fosse absolutamente estranho, então, seria, por conseguinte, incompreensível.” (JAUSS, 1994b tradução nossa).

Ao basearmos nossa discussão nessa relação, obra-mundo, chegaremos a uma conclusão próxima da de Ricoeur (2013), que considera haver, no interior do texto literário "uma proposição de mundo, de um mundo tal como posso habitá-lo para nele projetar um de meus possíveis mais próprios. É o que chamo de o mundo do texto, o mundo próprio a este texto único.” (RICOEUR, 2013, p. 66, grifo do autor). Inspirado por essa observação — que já havia sido feita por Aristóteles, ao formular sua ideia de mimesis — o crítico francês afirma que "[...] o texto a ser interpretado é a própria realidade e seu encadeamento (Zusamenhang).” (RICOEUR, 2013, p. 30). 
acredite na realidade do que ler, bem como seja afetado, isto é, sinta as mesmas emoções dos personagens. Mas, diante da possibilidade de realidade, o que seria o personagem, senão um ser real, na medida do possível. Pensando nisso, Candido questiona a existência do personagem:

\begin{abstract}
A personagem é um ser fictício, - expressão que soa como paradoxo. De fato, como pode uma ficção ser? Como pode existir o que não existe? No entanto, a criação literária repousa sobre este paradoxo, e o problema da verossimilhança no romance depende desta possibilidade de um ser fictício, isto é, algo que, sendo uma criação da fantasia, comunica a impressão da mais lídima verdade existencial. Podemos dizer, portanto, que o romance se baseia, antes de mais nada, num certo tipo de relação entre o ser vivo e o ser fictício, manifestada através da personagem, que é concretização deste. (CANDIDO, 2014, p. 55)
\end{abstract}

Já tomados pela questão de realidade no texto, ao observar a morte de Aquiles, Scholes e Kellogg (1977) afirmam que "a cena é mimética. A morte é comum a todos os homens. Sua inevitabilidade faz de Aquiles um homem, além de ser um herói." (SCHOLES; KELLOGG, 1977, p. 113). Se levarmos em consideração o fato de que, após a morte, uma pessoa continua existindo na lembrança, embora não exista mais concretamente, nada nos impede de considerarmos o personagem como um ser real, que possui uma certa personalidade, se relaciona com outras pessoas e tem suas próprias crenças, sonhos, medos, etc. É tomado por essa natureza realística da narrativa que Oliveira (2015) sugere que Nhô Augusto seja considerado um santo, com base na santificação popular.

De um modo ou de outro, devemos admitir que, no mundo do texto, como pontua Ricoeur (2013), "São as personagens (e o mundo fictício da cena) que 'absorveram' as palavras do texto e passam a constituí-las, tornando-se a fonte delas - exatamente como ocorre na realidade." (CANDIDO, 2014, p. 29). Quando o narrador de "A hora e vez de Augusto Matraga" afirma que a história pela qual estamos andando é uma história inventada, ele soa totalmente irônico, uma vez que, em tudo, a história assume um alto teor de realidade, o que envolve ainda mais o leitor em sua leitura. $\mathrm{O}$ que poderia ser questionado seria a sobrevivência de Nhô Augusto à queda do barranco, não obstante, não somos informados sobre a altura deste, dando a entender que seria de uma altura passível de sobrevivência em caso de queda. 
Inspirado na ideia de enunciação de Émile Benveniste (2005), de que o discurso seria centrado num $e u$ e que, por isso, não poderia se referir senão a um eu, o sujeito do discurso, Ricoeur (2013) considera que o texto literário seja de natureza discursiva, tendo em vista a concretização deste como um evento.

[...] o discurso é sempre discurso a respeito de algo: refere-se a um mundo que pretende descrever, exprimir ou representar. [...] é no discurso que todas as mensagens são trocadas. Neste sentido, só o discurso possui, não somente um mundo, mas o outro, outra pessoa, um interlocutor ao qual se dirige. Neste último sentido, o evento é o fenômeno temporal da troca, o estabelecimento do diálogo, que pode travar-se prolongar-se ou interromperse. (RICOEUR, 2013, p. 54-55)

Essa natureza discursiva do texto literário foi observada, também, por Poulet (1969), que considera, no ato da leitura, pensar os pensamentos de outrem, isto é, os pensamentos dos personagens. Não obstante, tal observações já haviam sido feitas, novamente, por Aristóteles, ao formular sua ideia de katharsis, que, por sua vez, será a base de desenvolvimento da ideia de Experiência estética de Jauss (1974) que, citando aquele, diz que "De acordo com Aristóteles, a catarsis ocorre quando o expectador da tragédia pode se colocar tão completamente no lugar do herói imerecidamente sofredor que ele sinta pelo herói o que ele sentiria senão somente por si mesmo.” (JAUSS, 1974, p. 287-288 tradução nossa). Considerando essa tomada de lugar, também, como já dissemos, observada por Poulet (1969), Jauss (1982) assegura que

\begin{abstract}
A experiência estética ocorre antes que haja cognição e interpretação do significado de uma obra e, certamente, antes de qualquer reconstrução de intenção do autor. A experiência primária de uma obra de arte acontece na orientação ao seu efeito estético, numa compreensão que é prazer e num prazer que é cognitivo. (JAUSS, 1982, p. 29 tradução nossa)
\end{abstract}

Ao considerar essa estreita relação entre o leitor e o personagem, Jauss (1974) considera necessário estabelecer uma distinção entre o ato da leitura e sua crítica, asseverando que

Hermeneuticamente, nós devemos distinguir entre um primeiro e segundo nível de experiência estética. A compreensão da intenção, como toda explicação de uma 
estética, quando o expectador ou leitor volta-se criticamente à sua experiência estética primária. O primeiro, o nível pré-refletivo da percepção estética é a estrutura comunicativa em prol de uma consciência imaginativa que é preparada para entrar em identificação emocional com a ação e situação do personagem. (JAUSS, 1974, p. 287 tradução nossa).

Ao considerarmos esses dois momentos da experiência estética, podemos observar que, de modo a fazer jus ao texto, no ato da crítica, o estudioso deve repetir sua leitura, dessa vez, criticamente, uma vez que, numa leitura inicial, é muito provável que este se perca em sua interação com o personagem.

\section{CONSIDERAÇÕES FINAIS}

Se a obra literária é baseada num mundo previamente dado, claro que - baseada numa suposta realidade, incluindo-se aí questões religiosas, superstições, etc. — a obra acrescenta ao mundo um poder ser, como supõe Ricoeur (2013). De qualquer forma, essa qualidade de real inerente ao mundo do texto - alicerçada por um conhecimento prévio Jauss (1994a) — bem como ao personagem e suas relações, permitem a experiência estética, um envolvimento entre leitor e personagem, como se, no ato da leitura, estes fossem um só, numa espécie de superposição de pensamento, visto que, embora o leitor incorpore outro pensamento, ele não abandona o seu, que é, por sua vez, a base para o desenvolvimento do outro pensamento, bem como a concretização do discurso e seu efeito estético.

Considerando os dois momentos da experiência estética, observadas por Jauss (1974), podemos supor que o crítico deve observar: a) até que ponto o leitor interage com o personagem, isto é, envolve-se de tal modo que sente as emoções deste como se fossem suas e, daí, desenvolve simpatia ou antipatia em relação a um personagem ou outro; b) até que ponto a interpretação do leitor é de natureza crítica, isto é, desenvolvida com base numa leitura crítica da obra, observando seu desenvolvimento, em contraste a uma interpretação de natureza emotiva, desenvolvida com base no envolvimento emocional do leitor com o personagem.

Tomando como ponto de discussão essas observações, podemos dizer que a leitura de Sousa (2014), embora cometendo alguns pequenos equívocos, é uma leitura mais consciente e analítica 
em relação a obra, enquanto que a leitura de Oliveira (2015) configura-se como uma leitura mais emotiva, isto é, guiada por uma suposta emoção, baseada, provavelmente, em suas crenças, o que o leva a considerar o personagem santo.

Faz-se crucial, portanto, uma distinção entre leitura crítica e emotiva, observados os elementos fundamentais para tal relação, como o conhecimento prévio, o mundo do texto e sua discursividade.

\section{REFERÊNCIAS}

BENVENISTE, Émile, Problemas de linguística geral I. tradução de Maria da Glória Novak e Maria Luisa Neri: rev. prof. Isaac Nicolau Salum. Campinas: Ponte, 2005.

CANDIDO, Antonio et alli. A Personagem de Ficção. São Paulo: Perspectiva, 2014.

ECO, Umberto. Obra aberta: formas e indeterminações nas poéticas contemporâneas. $10^{\mathrm{a}}$ ed. São Paulo: Perspectiva, 2015.

FREXEIRO, Fábio. Da razão à emoção II: ensaios rosianos, outros ensaios e documentos. Rio de Janeiro: Tempo Brasileiro, 1971.

JAUSS, Hans Robert. A história da literatura como provocação à teoria literária. Trad. Sérgio Tellaroli. São Paulo: Ática, 1994a.

Levels of identification of hero and audience. New Literary History, Charlottesville, v. 5, n. 2, p. 283-317, Winter, 1974.

Literary Experience and Literary Hermeneutics. Trad. Michael Shaw. Minneapolis: University of Minnesota Press, 1982.

Wege des Verstehens. München: Fink, 1994b.

OLIVEIRA, Wellington Costa de. A construção do santo popular no conto "A hora e vez de Augusto Matraga” da obra Sagarana. Diamantina, 2015. 99 p. Dissertação de Mestrado em ciências humanas da Universidade Federal dos Vales do Jequitinhonha e Mucuri.

POULET, Georges. Phenomenology of Reading. New Literary History, Charlottesville, v. 1, n. 1, p. 53-68, out., 1969.

RICOEUR, Paul. Interpretação e ideologias. Trad. Hilton Japiassu. Rio de Janeiro: Francisco Alves, 2013.

ROLIM, Anderson Teixeira. Bandidos e santos: um diálogo literário. Londrina, 2005. 100 p. Dissertação de Mestrado em Letras da Universidade Estadual de Londrina.

ROSA, João Guimarães. Sagarana. ed. 27ª . Rio de Janeiro: José Olympio, 1983.

SCHOLES, Robert; KELLOGG, Robert. A natureza da narrativa. Trad. Gert Meyer. rev. téc. Afrânio Coutinho. São Paulo: McGraw-Hill do Brasil, 1977.

SOUSA, Maria do Perpétuo Socorro Guterres de. Guimarães Rosa: travessia. Natal, 2014. 127 p. Tese da Universidade Federal do Rio Grande do Norte. 
REVISTA DO PROGRAMA DE PÓS-GRADUAÇÃO EM COMUNICAÇÃO, LINGUAGENS E CULTURA DA UNIVERSIDADE DA AMAZÔNIA

Recebido em 05 Out 2019 ｜Ａprovado em 01 Nov 2019

Antonio Daniel FÉLIX

É mestrando em Letras pela Universidade Federal do Pará (2018-2020); possui graduação em Letras - Língua Portuguesa pelo Instituto Federal de Educação, Ciência e Tecnologia do Pará (2018).

Sílvio Augusto de Oliveira HOLANDA

Possui graduação em Letras (Português/Francês) pela Universidade Federal do Pará (1990), mestrado em Letras/Teoria Literária pela Universidade Federal do Pará (1994), doutorado em Letras (Teoria Literária e Literatura Comparada) pela Universidade de São Paulo (2000) e pós-doutorado em Estudos Românicos pela Universidade de Lisboa (2007). Atualmente é professor associado IV da Universidade Federal do Pará, tendo sido coordenador do Programa de Pós-graduação em Letras (2009-2011) da referida instituição. Desde 2001, é membro permanente do corpo docente do Programa de Pós-Graduação em Letras da UFPA. Dirige a Faculdade de Letras (2017-2019) da UFPA. Tem experiência na área de Letras, atuando principalmente nos seguintes temas: Guimarães Rosa, Literatura brasileira, literatura da Amazônia e recepção crítica. 